\title{
PENGARUH ORIENTASI PASAR DAN KOMPETENSI SUMBERDAYA MANUSIA TERHADAP LOYALITAS PELANGGAN MELALUI KEPUASAAN PELANGGAN
}

\author{
Ricky Indra Gunawan ${ }^{1}{ }^{*}$, Moeljadi $^{1}$, Siti Aisjah ${ }^{1}$ \\ ${ }^{1}$ Fakultas Ekonomi dan Bisnis, Universitas Brawijaya Malang \\ * rickyindra66@gmail.com
}

\begin{abstract}
:
The purpose of this research is to analyze the affect of market orientation and human resources competence to customer loyalty through customer satisfaction in Rumah Sakit Islam Malang. The analysis tool in this research uses partial least square (PLS). The result shows that : 1) market orientation has a significant impact towards customer loyalty, 2) human resource competency does not have a significant impact towards customers loyalty, 3) market orientation has a significant impact towards customers satisfaction, 4) human resource competency has a significant impact towards customer satisfaction, 5) market orientation and human resource competency have a significant impact towards customers loyalty through customers satisfaction
\end{abstract}

Keywords: Market orientation, human resource competency, customer satisfaction, customer loyalty

\section{PENDAHULUAN}

Pemahaman yang baik mengenai pelanggan, akan mendorong manajemen untuk memahami dengan benar apa yang menjadi keinginan dan kebutuhan pelanggan. Dengan mengetahui keinginan dan kebutuhan pelanggan, pihak perusahaan dituntut untuk mampu menyediakan produk atau jasa yang baik bagi konsumen. Saat perusahaan mampu menciptakan/ menyediakan produk atau jasa yang baik sesuai dengan keinginan dan kebutuhan pelanggan dapat dipastikan pelanggan akan membeli produk atau jasa perusahaan tersebut. Kemampuan perusahaan untuk memahami keinginan dan kebutuhan pelanggan dan menyediakan produk atau jasa yang diinginan dan dibutuhan pelanggan dikenal dengan istilah orientasi pada pasar atau market orientation Engel (2012).

Perspektif bisnis yang membuat pelanggan sebagai titik penekanan bagi pandangan operasi secara menyeluruh dari suatu perusahaan dinamakan sebagai orientasi pasar yang terdiri dari orientasi terhadap pelanggan (consumer orientation), dan koordinasi internal organisasi (Cravens, 2006). Bisnis yang berorientasi pasar akan terjadi bila budaya suatu perusahaan secara sistematis dan menyeluruh percaya pentingnya penciptaan nilai yang superior bagi pelanggan (Cravens, 2006). Arah pergerakan pemasaran strategik kepada konsep marketisasi sebagai manifestasi dari konsep orientasi pasar perlu dipertimbangkan sebagai fokus utama kebijakan dalam upaya pencapaian kepuasaan pelanggan yang diharapkan juga akan berujung kepada loyalitas pelanggan. Pentingnya loyalitas pelanggan bagi institusi penyedia produk atau layanan tidak diragukan lagi. Setiap penyedia produk atau layanan sangat mengharapkan dapat mempertahankan pelanggannya dalam jangka panjang, bahkan jika mungkin untuk selamanya. 
Pihak organisasi rumah sakit melalui berbagai kebijakannya telah berupaya untuk memberikan layanan kesehatan yang bermutu sesuai dengan konsep yang sering didengungkan yang dikenal dengan istilah pelayanan prima. Ini terlihat dari upaya pihak rumah sakit untuk menyediakan sarana dan prasarana kesehatan maupun upaya mempersiapkan sumberdaya manusianya. namun dari sisi pelanggan konsep layanan prima yang dimaksud dikembalikan kepada apa yang diharapkannya dibandingkan dengan jasa yang diterimanya. Hal ini menyebabkan kesenjangan sering terjadi antara apa yang difikirkan manajemen tentang jasa yang berkualitas dengan apa yang dimaksudkan pelanggan tentang jasa yang berkualitas tersebut. Akibatnya manajemen dan pelanggan memiliki persepsi yang berlainan untuk memberikan suatu label bahwa jasa yang diberikan telah berkualitas. Dari perkembangan konsep pemasaran yang ada telihat mulai adanya pergeseran rumah sakit dari dokter sebagai sentral, menjadi pasien sebagai sentral. rumah sakit harus memperhatikan kebutuhan, keinginan dan nilai-nilai yang dirasakan pasien.

Beberapa rumah sakit di Indonesia saat ini juga gencar melakukan berbagai upaya untuk menumbuhkan dan mempertahankan loyalitas pelanggan mereka, diantaranya yaitu Rumah Sakit Islam Malang, yang melakukan beberapa upaya seperti pemilihan lokasi dan arsitektur bangunan rumah sakit yang disesuaikan dengan segmen pasar strategi diferensiasi dan pengelolaan keluhan pasien yang merupakan usaha - usaha jitu demi memikat pelanggan baru dan mempertahankan kesetiaan pelanggan lama.

Rumah Sakit Islam Malang merupakan rumah sakit swasta kelas $D$, yang mana tersedia 71 tempat tidur inap, 4 dari 71 tempat tidur di rumah sakit ini berkelas VIP keatas, Dari 71 tempat tidur inap di rumah sakit ini, mayoritas adalah kamar elas III sebanyak 36 kamar, jumlah dokter yang ada di rumah sakit ini adalah sebanyak 44 orang dan 26 diantaranya adalah dokter spesialis.
Berdasarkan informasi website Rumah Sakit Islam http://rumahsakit.findthebest. co.id/l/1034/RS-Islam-Malang) angka BOR (Bed Occupancy Ratio) di Rumah Sakit Islam Malang sebesar 34,5 \% dan Angka TOI (Turn Over Internal) sebesar 5,5 hari. BOR (Bed Occupancy Ratio) merupakan angka penggunaan tempat tidur. Indikator angka BOR ini memberikan gambaran tentang tinggi rendahnya tingkat pemanfaatan tempat tidur rumah sakit. Nilai parameter BOR yang ideal adalah antara 6085\%. Sedangkan TOI (Turn Over Interval) adalah rata-rata hari dimana tempat tidur tidak ditempati dari telah diisi ke saat terisi berikutnya. Idealnya tempat tidur kosong tidak terisi pada kisaran 1-3 hari. Gambaran hasil angka BOR dan TOR tesebut mencerminkan bahwa jumlah kamar yang digunakan di Rumah Sakit Islam Malang masih dibawah dari angka yang ideal dan masih dibawah angka rata-rata ideal pasien yang datang dan memanfaatkan berbagai fasilitas kesehatan di Rumah Sakit Islam Malang. Dengan adanya gambaran dari hasil tersebut sangat menarik untuk dilakukan penelitian. Menurut Muninjaya (2004) bahwa kurangnya jumlah pasien yang memanfaatkan fasilitas rumah sakit diakibatkan oleh beberapa faktor diantaranya kurangnya perhatian dari pihak manajemen rumah sakit dalam memperhatikan orientasi pasar yang sesuai dengan keinginan pasien, kompetensi yang yang kurang baik, dan sedikitnya nilai kepuasaan pelanggan yang mana akan juga mempengaruhi loyalitas pasien

Sebagaimana telah dijelaskan di atas bahwa sampai dengan akhir tahun 2014, ratarata (Bed Occupancy Rate) BOR di Rumah Sakit Islam Malang masih berada dikisaran $34,5 \%$. Nilai BOR ini lebih rendah dari nilai ideal BOR yang seharusnya yaitu $60-85 \%$, dan juga nilai TOI (Turn Over Ratio) idealnya untuk sebuah rumah sakit adalah 3 hari, sedangkan hasil angka yang didapat untuk Rumah Sakit Islam Malang adalah 5,5 hari. Kondisi ini tentunya tidak menguntungkan bagi pihak rumah sakit dan jika dibiarkan saja akan dapat mempengaruhi 
kinerja rumah sakit di masa datang. Kenyataan ini melatar belakangi perlunya pihak Rumah Sakit Islam Malang untuk menemukan cara guna meningkatkan nilai BOR-nya.

Ketidakpuasan pasien perlu ditindaklanjuti karena pada masa datang dapat menurunkan minat pasien untuk memiliki rawat inap di rumah sakit tersebut. Secara internal, perbaikan terhadap kualitas pelayanan ini pihak rumah sakit harus memiliki suatu manajemen yag baik dalam penentuan strategi yang akan dikembangkan dalam pengelolaan internalnya untuk menjawab keinginan yang ada di masyarakat, serta memperhatikan dan memperbaiki kualitas dari sumber daya manusianya dalam hal ini yaitu para karyawannya yang berhubungan langsung dengan penanganan rawat inap pasien di Rumah Sakit Islam Malang. Menurut Soedarmono dkk (2000) Pelayanan rumah sakit masih lebih berorientasi kepada tenaga kesehatan (provider oriented), belum beralih kepada pelayanan yang berorientasi kepada pasien (patient oriented)

Dalam pelayanan yang diberikan rumah sakit haruslah memperhatikan nilainilai pelanggan yang dibutuhkan dan diinginkan pasien agar pasien yang dirawat dirumah sakit tersebut merasa puas atas pelayanan yang telah diberikan, megingat rumah sakit adalah industri jasa yang melayani dibidang kesehatan, maka parameter untuk mengukur sejauh mana rumah sakit tersebut berhasilkan menjalankan manajemen rumah sakitnya dapat diukur dari hasil kepuasaan pasien dan loyalitas pasien yang ada di rumah sakit tersebut. Atas dasar latar belakang fenomena yang ada, serta informasi riset terdahulu, maka peneliti tertarik untuk mengembangkan penelitian tentang "Pengaruh Orientasi Pasar dan Kompetensi Sumberdaya Manusia Terhadap Loyalitas Pelanggan melalui Kepuasaan Pelanggan Rumah Sakit Islam Malang. Berdasarkan uraian latar belakang di atas, maka dapat dirumuskan permasalahan dalam penelitian ini secara lebih detail yaitu, apakah orientasi pasar berpengaruh terhadap loyalitas pelanggan, Apakah kompetensi sumberdaya manusia berpengaruh terhadap loyalitas pelanggan, Apakah orientasi pasar berpengaruh terhadap kepuasan pelanggan, Apakah kompetensi sumberdaya manusia berpengaruh terhadap kepuasan pelanggan.

\section{METODE}

Sesuai dengan pokok masalah dan tujuan penelitian yang telah dirumuskan, maka Jenis penelitian ini adalah explanatory research. Menurut Hasan (2002) penelitian yang bersifat penjelasan ini (explanatory research) adalah penelitian yang dalam proses pengujiannya menggunakan data yang sama, dimana peneliti berusaha menunjukkan suatu hubungan kausal atau sebab akibat antara variabel-variabel dalam penelitian dengan melakukan pengujian hipotesis. Dalam Sugiyono (2004) juga dijelaskan bahwa penelitian menurut tingkat eksplanasi adalah penelitian yang bermaksud menjelaskan kedudukan variabel-variabel yang diteliti serta hubungan antara satu variabel dengan variabel yang lain.

Pendekatan yang dipakai dalam penelitian ini adalah pendekatan kuantitatif dengan melakukan penelitian yang berkaitan pada survei, dan sampel penelitian ini mengambil pada populasi, serta menggunakan instrumen kuesioner sebagai alat pengumpulan data. Rentang waktu dalam penelitian ini adalah secara cross section, yakni pengumpulan data pada satu rentang waktu tertentu. Diagram jalur dalam penelitian ini adalah melihat kepuasaan pelanggan dalam memediasi pengaruh orientasi pasar dan kompetensi sumberdaya manusia terhadap loyalitas pelanggan pada Rumah Sakit Islam Malang.

Penelitian ini dilakukan pada Rumah Sakit Islam Malang, Jl. MT Haryono No. 139 Malang, adapun alasan memilih tempat ini sebagai lokasi penelitian adalah karena Rumah Sakit Islam Malang merupakan salah satu rumah sakit swasta yang ada di kota malang yang mana memiliki konsep rumah sakit dengan mengutamakan keinahan taman nya yang berada di lokasi rumah sakit islam malang, rumah sakit ini memiliki 44 dokter 
yang rata rata diatas rumah sakit yang ada di jawa timur pada umumnya, tetapi jika dilihat dari hasil tingkat bed occupancy rating (BOR) rumah sakit tesebut masih dibawah nilai angka standart yang seharusnya dimiliki oleh sebuah rumah sakit, oleh karena itu peneliti ingin meneliti dengan adanya fenomena tersebut yang terkait dengan peran kepuasaan pelanggan dalam memediasi pengaruh orientasi pasar dan kompetensi sumberdaya manusia terhadap loyalitas pelanggan.

Metode pengumpulan data dengan menggunakan instrumen pernyataan tertulis yang ditujukan kepada responden, dan dirancang secara khusus untuk memperoleh informasi yang akan digunakan dalam penelitian ini. Metode ini dilakukan dengan memberikan pertanyaan atau pernyataan terstruktur dan sistematis yang berkaitan dengan masalah orientasi pasar, kompetensi sumberdaya manusia, kepuasan pelanggan dan loyalitas pelanggan yang diangkat dalam penelitian ini, serta wawancara terstruktur terhadap responden yang berpedoman pada kuesioner untuk memperjelas pertanyaan sehingga diperoeh jawaban yang baik dan benar dan kuisioner akan diberikan pada hari terakhir pasien tersebut menjalani proses rawat inap di Rumah Sakit Islam Malang. Instrumen atau kuesioner yang telah dirancang sedemikian rupa tersebut akan diberikan secara langsung kepada responden yaitu pasien rawat inap di Rumah Sakit Islam Malang.

\section{HASIL}

\section{Gambaran Umum Rumah Sakit Islam Malang}

Rumah Sakit Islam Malang adalah rumah sakit dengan kelas $\mathrm{C}$ yang didirikan pada tanggal 28 Agustus 1994 yang diresmikan oleh presiden RI Bpk K.H Abdurahman Wahid (Gusdur). Lokasi Rumah Sakit Islam Malang ini tepatnya berada di Jl Mt Haryono No 139 Kelurahan Dinoyo Kota Malang. Rumah Sakit Islam Malang memiliki beberapa ruangan totalnya 102 kamar, yang diantaranya terdiri dari : Ruangan VIP (kelas orchid), sebanyak 15 kamar, kelas Jasmine I \& II (utama) sebanyak 9 kamar, kelas I (kelas tulip) sebanak 8 kmar, kelas II teratai sebanyak 8 kamar, kelas III dahlia sebanyak 27 kamar, kelas Gladiol-isolasi sebanyak 4 kamar, kamar bersalin (rosemary, mawar, aster) sebanyak 8 kamar, ruang perinatal sebanak 9 kamar, ruang kelas anak bluberry \& strawberry sebanyak 9 kamar, dan ICU / ruang Eidelweis sebanyak 5 kamar. Selain itu juga terdapat juga ruang opersai, labolatorium, farmasi dll. Rumah Sakit Islam Malang juga memiliki tenaga kerja baik dari medis mupun non medis sebanyak 444 pegawai yang diantaranya terdiri dari : Dokter umum dan Spesialis, Tenaga Keperawatan, Tenaga Penunjang Medis, Tenaga non Medis,

\section{Karakteristik Responden}

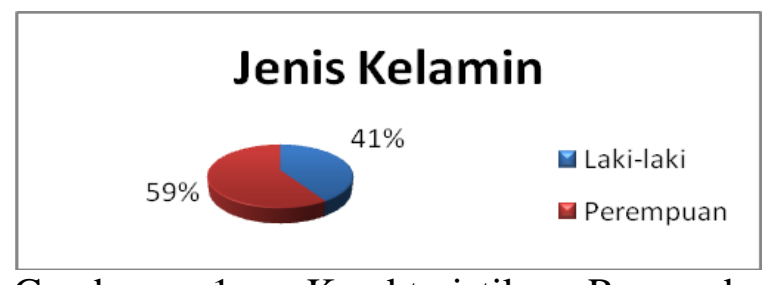

Gambar 1. Karakteristik Responden Berdasarkan Jenis Kelamin

Berdasarkan gambar 1 dapat diketahui bahwa dari 68 pasien rawat inap di Rumah Sakit Islam Malang, 59\% pasien berjenis kelamin perempuan. Sedangkan $41 \%$ pasien berjenis kelamin laki-laki. Kondisi ini dipengaruhi oleh jumlah dan jenis pelayanan rawat inap yang dapat dimanfaatkan semua golongan baik laki-laki maupun perempuan. Namun apabila melihat perbandingan jumlah responden, perempuan memiliki jumlah lebih banyak daripada lakilaki.

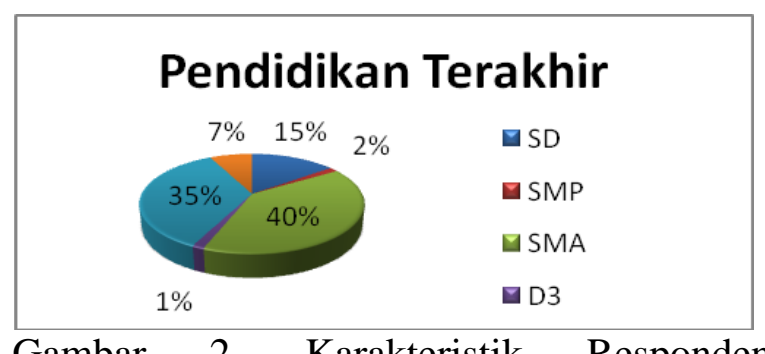

Gambar 2. Karakteristik Responden Berdasarkan Pendidikan 
Berdasarkan gambar 2 dapat diketahui bahwa dari 68 pasien rawat inap di Rumah Sakit Islam Malang, 40\% pasien berpendidikan terakhir SMA, 35\% pasien berpendidikan terakhir Sarjana, 15\% pasien berpendidikan terakhir SD, 7\% pasien berpendidikan terkahir pascasarjana, 2\% pasien berpendidikan terakhir SMP, dan 1\% pasien berpendidikan terakhir D3. Dengan banyaknya responden dengan penidikan tinggi di satu sisi dapat menguntungkan petugas dalam menciptakan komunikasi dua arah yang baik dengan pasien sehingga lebih mudah untuk dipahami terutama dalam pemahaman terhadap diagnosa penyakit yang diderita pasien dan begitu juga sebaliknya. Di sisi lain, informasi tersebut menandakan perlunya kualitas petugas yang baik dalam kemampuannya memberikan pelyanan mengingat responden yang berpendidikan tinggi cenderung kritis dalam memanfaatkan pelayanan yang diberikan oleh pihak rumah sakit.

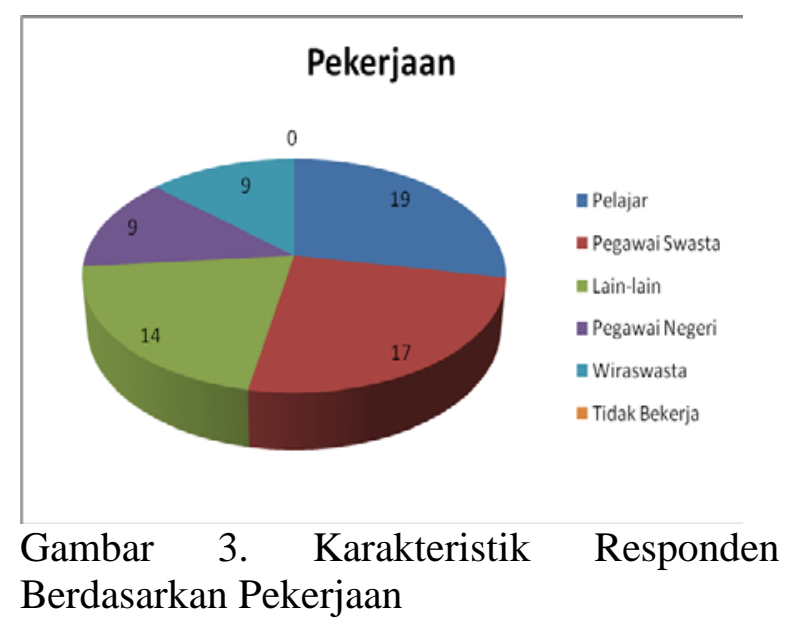

Berdasarkan gambar 3dapat diketahui bahwa dari 68 pasien rawat inap di Rumah Sakit Islam Malang, 28\% pasien merupakan pelajar, 25\% pasien bekerja sebagai pegawai swasta, 21\% pasien menjawab lainnya untuk status pekerjaan mereka, 13\% pasien bekerja sebagai pegawai negeri dan wiraswasta, dan tidak ada pasien yang tidak bekerja. Hal ini menunjukan bahwa pasien yang memilih rumah sakit islam untuk rawat inap sangatlah beragam dari segi profesinya pasien, dan jumlah terbesar didominasi oleh pelajar yang rata-rata adalah pelajar dari mahasiswa prantauan yang kost di sekitaran Rumah Sakit Islam Malang dan urutan terbesar kedua adalah pasien dengan profesi yang berkerja di perusahaan swasta dan disusul dengan pasien yang berprofesi sebagai pegawai negeri dan juga wiraswasta, maka dapat dikatakan bahwa pelayanan rawat inap rumah sakit islam dimanfaatkan oleh banyak orang yang profesi pekerjaannya cukup beragam.

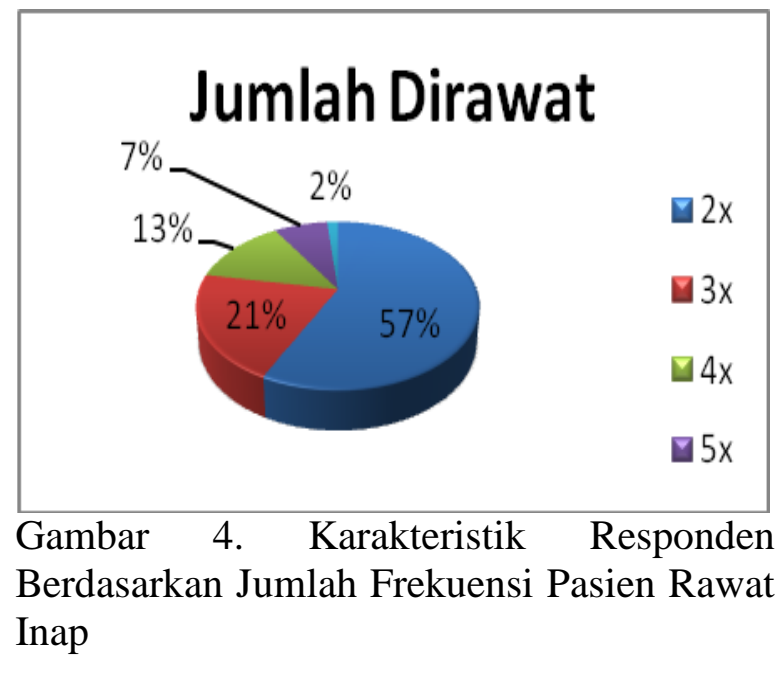

Berdasarkan gambar 4 dapat diketahui bahwa dari 68 pasien rawat inap di Rumah Sakit Islam Malang, 57\% pasien pernah dirawat sebanyak dua kali di Rumah sakit Islam Malang, 21\% pasien pernah dirawat sebanyak tiga kali di Rumah Sakit Islam Malang, 13\% pasien pernah dirawat sebanyak empat kali di Rumah Sakit Islam Malang, 7\% pasien pernah dirawat sebanyak lima kali di Rumah Sakit Islam Malang, dan 2\% pasien pernah dirawat sebanyak delapan kali di Rumah Sakit Islam Malang. Hal ini dapat menunjukan tingkat loyalitas pasien rawat inap terhadap pemanfaatan fasilitas rawat inap di rumah sakit islam malang. Dari data yang didapatkan pasien yang memanfaatkan fasilitas rawat inap di rumah sakit islam malang sebanyak dua kali paling tinggi prosentasenya disusul dengan pasien yang pernah dirawat inap sebanyak tiga ali, empat kali, lima kali, dan delapan kali. 


\section{Kelas Rawat Inap}

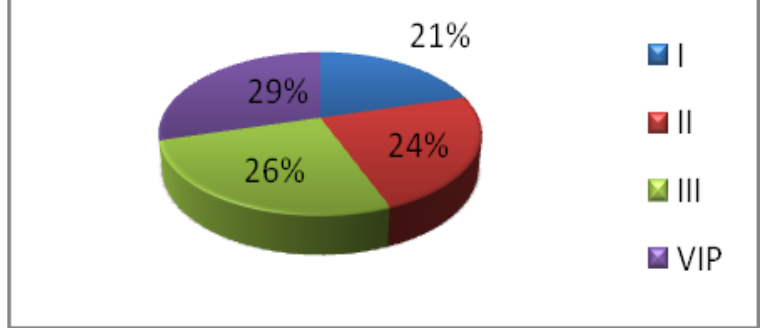

Gambar 5. Karakteristik Responden Berdasarkan Kelas Rawat Inap

Berdasarkan gambar 5 dapat diketahui bahwa dari 68 pasien rawat inap di Rumah Sakit Islam Malang, 29\% pasien dirawat di kelas VIP, 26\% pasien dirawat di kelas III, 24\% pasien dirawat di kelas II, dan $21 \%$ pasien dirawat di kelas I. hal ini menunjukan bahwa hamper semua kelas rawat inap di rumah sakit islam malang diminati oleh para pasien, jika membahas kelas rawat inap akan berhubungan secara linear dengan harga yang dikeluarkan karena semakin tinggi kelas rawat inap yang dipilih maka fasilitas yang didapatkan juga akan semakin baik dan hal itu juga akan menimbulkan biaya rawat inap yang tarifnya lebih mahal dibanding dengan kelas rawat inap yang biasa. Dari hasil yang didapatkan jumlah terbesar kelas rawat inap yang dimanfaatkan adalah kelas VIP yang mana ini merupakan kelas rawat inap yang paling mahal harganya dibanding kelas lainnya, maka dapat dikatakan secara kemampuan finansial pasien rawat inap rumah sakit islam malang dalam katagori menenggah ke atas yang lebih condong memilih pelayanan dengan fasilitas terbaik, walaupun harga semakin mahal tidak menjadi masalah, tetapi juga ada beberapa pasien yang juga memanfaatkan kelas satu, dua, dan kelas tiga.

\section{PEMBAHASAN}

\section{Pengujian Hipotesis}

\section{Konversi Diagram Jalur ke dalam Model Pengukuran}

Konversi diagram jalur ke dalam model pengukuran dimaksudkan untuk mengetahui pengaruh antar variabel yang dijelaskan oleh efek pada model, yaitu efek langsung dan efek tidak langsung.

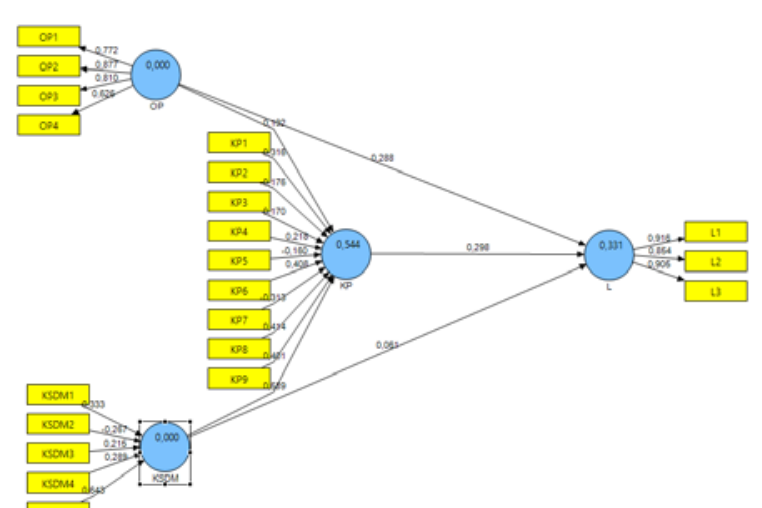

Gambar 6. Pengaruh Langsung dan Tidak Langsung

Adapun pengaruh secara langsung maupun secara tidak langsung sebagaimana sebagai berikut:

Tabel 1. Pengaruh Langsung dan Tidak Langsung

\begin{tabular}{|l|l|l|c|c|c|}
\hline \multicolumn{1}{|c|}{ Eksogen } & Endogen & Intervening & $\begin{array}{c}\text { Direct } \\
\text { Coefficient }\end{array}$ & $\begin{array}{c}\text { Indirect } \\
\text { Coefficient }\end{array}$ & Total \\
\hline $\begin{array}{l}\text { Orientasi } \\
\text { Pasar }\end{array}$ & $\begin{array}{l}\text { Kepuasan } \\
\text { Pelanggan }\end{array}$ & - & $0.192^{*}$ & - & 0.192 \\
\hline $\begin{array}{l}\text { Kompetensi } \\
\text { Sumberdaya } \\
\text { Manusia }\end{array}$ & $\begin{array}{l}\text { Kepuasan } \\
\text { Pelanggan }\end{array}$ & - & $0.589^{*}$ & - & 0.589 \\
\hline $\begin{array}{l}\text { Orientasi } \\
\text { Pasar }\end{array}$ & $\begin{array}{l}\text { Loyalitas } \\
\text { Pelanggan }\end{array}$ & - & $0.288^{*}$ & - & 0.288 \\
\hline $\begin{array}{l}\text { Kompetensi } \\
\text { Sumberdaya } \\
\text { Manusia }\end{array}$ & $\begin{array}{l}\text { Loyalitas } \\
\text { Pelanggan }\end{array}$ & - & 0.061 & - & 0.061 \\
\hline $\begin{array}{l}\text { Kepuasan } \\
\text { Pelanggan }\end{array}$ & $\begin{array}{l}\text { Loyalitas } \\
\text { Pelanggan }\end{array}$ & - & $0.298^{*}$ & - & 0.298 \\
\hline $\begin{array}{l}\text { Orientasi } \\
\text { Pasar }\end{array}$ & $\begin{array}{l}\text { Loyalitas } \\
\text { Pelanggan }\end{array}$ & $\begin{array}{l}\text { Kepuasan } \\
\text { Pelanggan }\end{array}$ & 0.192 & $0.057^{*}$ & 0.249 \\
\hline $\begin{array}{l}\text { Kompetensi } \\
\text { Sumberdaya } \\
\text { Manusia }\end{array}$ & $\begin{array}{l}\text { Loyalitas } \\
\text { Pelanggan }\end{array}$ & $\begin{array}{l}\text { Kepuasan } \\
\text { Pelanggan }\end{array}$ & 0.589 & $0.175^{*}$ & 0.764 \\
\hline
\end{tabular}

Sumber: data primer yang diolah Tahun 2016

Keterangan : * (significant)

Berdasarkan tabel 1 dapat diketahui bahwa model struktural yang terbentuk adalah

Persamaan 1 : Kepuasan Pelanggan $=0.192$ Orientasi Pasar +0.589 Kompetensi Sumberdaya Manusia

Dari persamaan 1 dapat diinformasikan bahwa

1. Koefisien direct effect orientasi pasar terhadap kepuasan pelanggan sebesar 0.192 menyatakan bahwa orientasi pasar 
berpengaruh positif dan signifikan terhadap kepuasan pelanggan. Hal ini berarti semakin baik orientasi pasar maka cenderung dapat meningkatkan kepuasan pelanggan.

2. Koefisien direct effect kompetensi sumber daya manusia terhadap kepuasan pelanggan sebesar 0.589 menyatakan bahwa kompetensi sumberdaya manusia berpengaruh positif dan signifikan terhadap kepuasan pelanggan. Hal ini berarti semakin baik kompetensi sumberdaya manusia maka cenderung dapat meingkatkan kepuasan pelanggan.

Persamaan 2 : Loyalitas Pelanggan $=0.288$ Orientasi Pasar +0.061 Kompetensi Sumberdaya Manusia +0.298 Kepuasan Pelanggan

Dari persamaan 2 dapat diinformasikan bahwa

1. Koefisien direct effect orientasi pasar terhadap loyalitas pelanggan sebesar 0.288 menyatakan bahwa orientasi pasar berpengaruh positif dan signifikan terhadap loyalitas pelanggan. Hal ini berarti semakin baik orientasi pasar maka cenderung dapat meningkatkan loyalitas pelanggan.

2. Koefisien direct effect kompetensi sumberdaya manusia terhadap loyalitas pelanggan sebesar 0.061 menyatakan bahwa kompetensi sumberdaya manusia berpengaruh positif dan tidak signifikan terhadap loyalitas pelanggan. Hal ini berarti semakin baik kompetensi sumberdaya manusia maka cenderung dapat meningkatkan loyalitas pelanggan, namun pengaruh tersebut tidak signifikan.

3. Koefisien direct effect kepuasan pelanggan terhadap loyalitas pelanggan sebesar 0.298 menyatakan bahwa kepuasan pelanggan berpengaruh positif dan signifikan terhadap loyalitas pelanggan. Hal ini berarti semakin baik kepuasan pelanggan maka cenderung dapat meningkatkan loyalitas pelanggan.

4. Koefisien indirect effect orientasi pasar terhadap loyalitas pelanggan melalui kepuasan pelanggan sebesar 0.057 menyatakan bahwa orientasi pasar berpengaruh positif dan signifikan terhadap loyalitas pelanggan melalui kepuasan pelanggan. Hal ini berarti semakin baik kepuasan pelanggan yang disebabkan meningkatnya orientasi pasar maka cenderung dapat meningkatkan loyalitas pelanggan.

5. Koefisien indirect effect kompetensi sumberdaya manusia terhadap loyalitas pelanggan melalui kepuasan pelanggan sebesar 0.175 menyatakan bahwa kompetensi sumberdaya manusia berpengaruh positif dan signifikan terhadap loyalitas pelanggan melalui kepuasan pelanggan. Hal ini berarti semakin baik kepuasan pelanggan yang disebabkan meningkatnya kompetensi sumberdaya manusia maka cenderung dapat meningkatkan loyalitas pelanggan.

\section{Pengujian Signifikasi Pengaruh Variabel Eksogen terhadap Variabel Endogen}

Hipotesis 1 yaitu pengaruh orientasi pasar terhadap loyalitas pelanggan. Pada hasil pengujian yang tertera pada tabel di atas dapat diketahui bahwa nilai $\mathrm{T}$ statistics hubungan antara orientasi pasar terhadap loyalitas pelanggan adalah sebesar 2.484. Hasil pengujian tersebut menunjukkan bahwa nilai T statistics $>1$.96. Hal ini berarti terdapat pengaruh yang signifikan orientasi pasar terhadap loyalitas pelanggan. Dengan demikian hipotesis 1 terpenuhi.

Hipotesis 2 yaitu pengaruh kompetensi sumberdaya manusia terhadap loyalitas pelanggan. Pada hasil pengujian yang tertera pada tabel di atas dapat diketahui bahwa nilai $\mathrm{T}$ statistics hubungan kompetensi sumberdaya manusia terhadap loyalitas pelanggan adalah sebesar 0.638. Hasil pengujian tersebut menunjukkan bahwa nilai T statistics $<1.96$. Hal ini berarti tidak terdapat pengaruh yang signifikan kompetensi sumberdaya manusia terhadap loyalitas pelanggan. Dengan demikian hipotesis 2 tidak terpenuhi.

Hipotesis 3 yaitu pengaruh orientasi pasar terhadap kepuasan pelanggan. Pada 
hasil pengujian yang tertera pada tabel di atas dapat diketahui bahwa nilai $\mathrm{T}$ statistics hubungan antara orientasi pasar terhadap kepuasan pelanggan adalah sebesar 3.348. Hasil pengujian tersebut menunjukkan bahwa nilai T statistics $>1.96$. Hal ini berarti terdapat pengaruh yang signifikan orientasi pasar terhadap kepuasan pelanggan. Dengan demikian hipotesis 3 terpenuhi.

Hipotesis 4 yaitu pengaruh kompetensi sumberdaya manusia terhadap kepuasan pelanggan. Pada hasil pengujian yang tertera pada tabel di atas dapat diketahui bahwa nilai $\mathrm{T}$ statistics hubungan antara kompetensi sumberdaya manusia terhadap kepuasan pelanggan adalah sebesar 11.866. Hasil pengujian tersebut menunjukkan bahwa nilai T statistics $>1.96$. Hal ini berarti terdapat pengaruh yang signifikan kompetensi sumberdaya manusia terhadap kepuasan pelanggan. Dengan demikian hipotesis 4 terpenuhi.

Hipotesis 5 yaitu pengaruh kepuasan pelanggan terhadap loyalitas pelanggan. Pada hasil pengujian yang tertera pada tabel di atas dapat diketahui bahwa nilai $T$ statistics hubungan antara kepuasan pelanggan terhadap loyalitas pelanggan adalah sebesar 3.124. Hasil pengujian tersebut menunjukkan bahwa nilai $\mathrm{T}$ statistics $>1.96$. Hal ini berarti terdapat pengaruh yang signifikan kepuasan pelanggan terhadap loyalitas pelanggan. Dengan demikian hipotesis 5 terpenuhi.

\section{Implikasi Penelitian}

Implikasi dalam penelitian ini tebagi menjadi dua bagian, yaitu implikasi praktis dan implikasi teoritis. Implikasi teoritis berhubungan denngan pengembangan hasil penelitian bagi peneliti berikutnya terkait orientasi pasar, kompetensi sumberdaya manusia, kepuasan pelanggan, dan loyalitas pelanggan. Sedangkan implikasi praktis berhubungan dengan memberikan kontribusi manajerial bagi rumah sakit islam malang khususnya dalam mengembangkan dan meningkatkan pelayanan yang diberikan kepada pasien rawat inap berdasarkan dari hasil penelitian yang didapat.

\section{Implikasi Teoritis}

Temuan penting dan menarik dalam penelitian ini adalah adanya bukti secara empiris yang menunjukan bahwa dalam suatu kerangka konseptual penelitian, dimana orientasi pasar memiliki kontribusi yang kuat terhadap loyalitas pelanggan. Pada variabel kompetensi sumberdaya manusia tidak memiliki hubungan yang kuat dengan loyalitas pelanggan secara langsung, dimana kompetensi sumberdaya manusia memiliki hubungan yang kuat terhadap loyalitas pelanggan jika melalui kepuasan pelanggan. Variabel kepuasan pelanggan sendiri secara langsung mempunyai hubungan yang kuat terhadap kepuasan pelanggan. Dan variabel kepuasan pelanggan juga berhasil menjadi mediasi antara orientasi pasar dan kompetensi sumberdaya manusia terhadap loyalitas pelanggan. Hal ini menggambarkan bahwa jika rasa puas yang dialami oleh pelanggan maka secara langsung akan membuat rasa loyal pelanggan terhadap apa yang mereka rasakan sebelumnya. Orientasi pasar juga memiliki hubungan yang kuat terhadap loyalitas pelanggan baik secara langsung maupun tidak langsung, hal ini menggambarkan bahwa usaha orientasi pasar yang dilakukan dengan baik dengan memperhatikan aspek-aspek kebutuhan dan permintaan pelanggan akan menghasilkan kepuasan pelanggan dan rasa loyal yang biasa disebut dengan loyalitas pelanggan.

\section{Implikasi Praktis}

Orientasi pasar menunjukan pengaruh yang signifikan terhadap kepuasaan pelanggan maupun loyalitas pelanggan baik secara langsung maupun tidak langsung. Dengan ini manajemen Rumah Sakit Islam Malang dapat meningkatkan orientasi pasarnya melalui kemudahan pasien dalam memberikan saran dan keluhan, memiliki komitmen yang kuat dalam memberikan pelayanan sesuai kebutuhan pasien, memberikan manfaat yang baik selama melayani pasien, dan melakukan tindakan dengan respon yang cepat dan tanggap. Orientasi pasar yang baik akan membuat pengaruh yang positif melalui kepuasan 
pelanggan dan terciptanya loyalitas pelanggan.

Kompetensi sumberdaya manusia adalah hal yang penting dalam mencapai kepuasan pelanggan dan loyalitas pelanggan (pasien) rawat inap di rumah sakit islam malang. Oleh karena itu dengan kompetensi yang baik dimiliki oleh pegawai Rumah Sakit Islam Malang akan menciptakan kepuasan pelanggan yang mana setelah kepuasan pelanggan tercipta diharapkan timbulnya loyalitas pelanggan terhadap Rumah Sakit Islam Malang.

Loyalitas pelanggan didapat melalui kepuasan pelanggan sehingga pihak manajemen Rumah Sakit Islam Malang dapat diharapkan meningkatkan kepuasan pelanggan (pasiennya) melalui peningkatan program orientasi pasar yang sesuai dengan keinginan dan kebutuhan pasien juga meningkatan kompetensi, kemampuan dan pengetahuan tenaga ahli dalam memberikan pelayanan kepada pasiennya.

\section{Keterbatasan Penelitian}

Penelitian ini telah dilakukan sebagaimana langkah-langkah penelitian ilmiah yang baik namun demikian masih memiliki beberapa keterbatasan yang perlu dicermati dan diperhatikan. Keterbatasan tersebut adalah karakteristik responden di masing-masing daerah dan rumah sakit pasti berbeda, tergantung dari lingkungan kondisi yang dirasakan oleh pasien saat itu, sehingga hasil penelitian tidak bisa digeneralisir untuk pasien-pasien yang dirawat di rumah sakit lain dan di daerah lain

\section{Kesimpulan}

Berdasarkan tujuan dan hasil dalam pembahasan penelitian ini, maka diambil kesimpulan bahwa kepuasan pelanggan memiliki peran positif dalam memediasi pengaruh orientasi pasar dan kompetensi sumberdaya manusia terhadap loyalitas pelanggan Rumah Sakit Islam Malang, dimana kepuasan pelanggan dalam hal ini berperan sebagai variabel mediasi. Tetapi dalam hasil penelitian ini pengaruh mediasi dari kepuasan pelanggan merupakan mediasi secara parsial (partially mediated), sehingga ke depan diharapkan Rumah Sakit Islam Malang dapat lebih fokus dalam peningkatan orientasi passar dan kompetensi sumber daya manusianya untuk mencapai loyalitas pelanggan terhadap Rumah Sakit Islam Malang.

Rumah Sakit Islam Malang sebaiknya perlu memperhatikan kecepatan dalam menanggapi keluhan dan kebutuhan pasien rawat inap serta dapat memberikan solusi atas permasalahan yang dikeluhkan pasien. Rumah Sakit Islam Malang juga perlu mengutamakan konsep pelayanan yang berorientasikan kepada kebutuhan pasien sehingga akan menanamkan rasa aman, nyaman dan timbulnya rasa kepercayaan di benak pasien. Pada penelitian selanjutnya diharapkan dapat menambah variabel nilai pelanggan dan trust (kepercayaan) dalam mengukur kepuasan pelanggan dan loyalitas pelanggan (pasien)

Rumah Sakit Islam Malang seharusnya dapat meningkatkan kepuasan pelanggan an loyalitas pelanggan dengan meningkatkan kualitas layanan baik dari segi sumberdaya manusianya maupun programprogram yang berorientasikan kepada pasar (pelanggan) sehingga diharapkan dapat memberikan keunggulan layanan rumah sakit yang baik dibandingkan dengan rumah sakit lainnya yang sebanding dengan kelas Rumah Sakit Islam Malang

\section{DAFTAR PUSTAKA}

Craven, D.W. 2006. Pemasaran Strategis, (terjemahan). Erlangga, Jakarta

Engel, J.F, Pai, D.C., Norjaya, M.Y. and Wn, J.H (2012). Consumer Behavior. Cengage Learning Asia Pte Ltd, Singapore

Hasan, M. Iqbal. 2002. Pokok-pokok materi Metodologi Penelitian dan Aplikasi PLS, BPFE, Yogyakarta.

Muninjaya, A.AG. 2004 Manajemen Kesehatan, Penerbit EGC, Jakarta . 
Soejitno, Soedarmono dkk. 2002. Reformasi Perumahsakitan Indonesia. Grasindo, Jakarta.

Sugiono. 2009. Statistika untuk Penelitian. Cetakan keenam, Alfabeta, Bandung

Hair, et al. 2013. Multivariate Data Analysis 6th Ed. Pearson Education, New Jersey 